\title{
FAKTOR-FAKTOR YANG MEMENGARUHI TINGKAT PEMANFAATAN E-MARKETING TANI NIAGA OLEH PETANI KABUPATEN GROBOGAN
}

\author{
Ariska Rosadi Al Rasyid Shodiq ${ }^{1)}$, Wahyu Budi Priatna ${ }^{2)}$, dan Nunung Kusnadi ${ }^{3)}$ \\ ${ }^{1)}$ Program Magister Sains Agribisnis, Sekolah Pascasarjana Instutut Pertanian Bogor \\ ${ }^{2,3)}$ Departemen Agribisnis, Fakultas Ekonomi dan Manajemen, Institut Pertanian Bogor \\ 1) ariskarosadial@gmail.com \\ Diterima 12 April 2019/ Di setujui 29 Agustus 2019
}

\begin{abstract}
Most e-marketing is widely used for business activities by companies in marketing nonagribusiness products. This happens because agribusiness products have different characteristics from non-agribusiness products, that is perishable, voluminous, and bulky. Although in its development, agribusiness products can also be marketed through e-marketing. Tani Niaga is one of the e-marketing in the agribusiness sector, which managed by the Agriculture Service of Grobogan Regency (Dinas Pertanian Kabupaten Grobogan). The purpose of research are to identify factors that influence farmer to use Tani Niaga. The data were analyzed using Partial Least Square (PLS) to identify factors that influenced farmer to use Tani Niaga. The results of research showed that the individual characteristics of farmers and the characteristics of the Tani Niaga had significant effect on using Tani Niaga. The formal education was a dominant factor in individual characteristics of food farmers whose a significant effect on the level of using of the Tani Niaga, but a dominant factor in the horticulture farmers group was the courage to take risks. Moreover, the suitability of need was a dominant factor for the characteristic of Tani Niaga whose a significant effect on the level of using the Tani Niaga in the group of food farmers, but ease-of-use the Tani Niaga was a dominant factor for the group of horticultural farmers.
\end{abstract}

Keywords: agribusiness products, food farmers, horticulture farmers, information technology, SmartPLS

\begin{abstract}
ABSTRAK
Sebagian besar e-marketing banyak digunakan untuk kegiatan bisnis oleh perusahaan dalam memasarkan produk non-agribisnis. Hal Ini terjadi karena produk agribisnis memiliki karakteristik yang berbeda dengan produk non agribisnis, yaitu mudah rusak, volume besar, dan mengambil ruang besar. Meski dalam perkembangannya, produk agribisnis juga bisa dipasarkan melalui e-marketing. Tani Niaga adalah salah satu e-marketing di sektor agribisnis, yang dikelola oleh Dinas Pertanian Kabupaten Grobogan. Tujuan dari penelitian ini adalah untuk mengidentifikasi faktor-faktor yang mempengaruhi petani untuk memanfaatkan Tani Niaga. Data dianalisis menggunakan Partial Least Square (PLS) untuk mengidentifikasi faktorfaktor yang mempengaruhi petani dalam memanfaatkan Tani Niaga. Hasil penelitian menunjukkan bahwa karakteristik individu petani dan karakteristik Tani Niaga berpengaruh signifikan terhadap tingkat pemanfaatan Tani Niaga. Faktor karakteristik individu pada petani pangan yang dominan berpengaruh nyata terhadap tingkat pemanfaatkan Tani Niaga adalah pendidikan formal, sedangkan pada kelompok petani hortikultura adalah keberanian mengambil resiko. Faktor karakteristik Tani Niaga yang dominan berpengaruh nyata terhadap tingkat pemanfaatan Tani Niaga pada kelompok petani pangan adalah kesesuaian dengan
\end{abstract}


kebutuhan, sedangkan pada kelompok petani hortikultura adalah kemudahan untuk diaplikasikan.

Kata Kunci: petani hortikultura, petani pangan, produk agribisnis, SmartPLS, teknologi informasi

\section{PENDAHULUAN}

Di era globalisasi ini, Teknologi Informasi dan Komunikasi (TIK) berkembang dengan sangat pesat. Sejalan dengan berkembangnya TIK tersebut, muncul pemahaman baru mengenai paradigma pemasaran berupa konsep pemasaran modern melalui jaringan internet yang disebut dengan $e$ marketing (Eid dan Trueman, 2002; Chandra, 2006; Nurmalina, 2014). Emarketing merupakan bagian dari manajemen pemasaran yang memperhatikan perkembangan lingkungan yang dinamis, dimana internet menjadi alternatif media pemasaran yang efektif dan efisien. Emarketing menggambarkan penggunaan teknologi informasi dalam proses menginformasikan, mengomunikasikan, mempromosikan, menjual produk atau jasa (Kotler dan Armstrong, 2018). Emarketing juga merupakan suatu proses membangun dan mempertahankan hubungan dengan pelanggan melalui kegiatan pemasaran secara online (Mohammed et al., 2003). Adanya $e$ marketing merubah praktek pemasaran konvensional yang bersifat face to face ke arah interaksi modern berbasis elektronik yang lebih cepat, mudah, murah, dan akurat.

Sebagian besar e-marketing banyak dimanfaatkan untuk kegiatan bisnis oleh perusahaan-perusahaan dalam memasarkan produk atau jasa sesuai kebutuhan konsumen. Data dan Statistik Kementerian Komunikasi dan Informatika Republik Indonesia (2015 a dan b) menunjukkan bahwa klasifikasi produk yang dibeli secara online didominasi oleh kategori fashion dan aksesoris sebesar 37,6 persen, sedangkan klasifikasi jasa yang digunakan dalam transaksi online didominasi oleh kategori travel sebesar 35,3 persen.

Namun meskipun begitu, perkembangan pemasaran produk melalui internet kini merambah ke berbagai produk termasuk produk agribisnis. Banyak pelaku usaha agribisnis yang telah memanfaatkan $e$ marketing sebagai media pemasaran produk agribisnis, contohnya di Negara Cina dan Amerika Serikat (Liu et al., 2013; Lu, 2015). Di sisi lain, produk agribisnis memiliki keunikan bahkan perbedaan dengan produk non-agribisnis, seperti pakaian dan elektronik. Karakteristik umum produk agribisnis adalah mudah rusak (perishable), volume besar (voluminous), dan mengambil ruang besar (bulky) (Asmarantaka, 2014). Selain itu, karakteristik produk agribisnis juga bersifat musiman, ketergantungan pada alam, ketidakseragaman kualitas, penawaran produknya relatif kecil serta memiliki rantai pemasaran yang relatif panjang.

Pemanfaatan e-marketing untuk produk agibisnis pun mulai berkembang 
di Indonesia pada tahun 2016 melalui program Sinergi Aksi untuk Ekonomi Rakyat yang dicanangkan oleh pemerintah. Salah satu program Sinergi Aksi untuk Ekonomi Rakyat, yaitu mendayagunakan pelayanan digital untuk mendorong pemasaran produkproduk pertanian atau perikanan (Kemenkeu, 2016). Pemerintah berupaya mengenalkan dan mengimplementasikan sistem pemasaran produk hasil pertanian dengan sistem online melalui pengembangan sarana dan prasarana teknologi informasi sebagai upaya untuk memangkas rantai distribusi hasil produksi dari petani kepada konsumen agar dapat menjaga ketersediaan komoditas pertanian dan stabilitas harga sampai pada tingkat konsumen.

Adanya upaya pemerintah dalam hal pemasaran ternyata ditanggapi secara positif oleh pihak Dinas Pertanian Kabupaten Grobogan. Dilatarbelakangi oleh permasalahan pemasaran hasil pertanian yang terjadi di Kabupaten Grobogan, yaitu banyaknya keluhan yang sering muncul dari kalangan petani terkait harga produk hasil pertanian yang tidak sesuai dengan yang diharapkan dan adanya ketergantungan petani kepada tengkulak. Selain itu, Dinas Pertanian Kabupaten Grobogan juga melihat peluang dari perkembangan teknologi informasi serta menyadari pentingnya pentingnya e-marketing untuk memasarkan produk hasil pertanian bagi petani setempat. Hal inilah yang mendorong pihak dinas tersebut dalam membangun serta menerapkan $e$ marketing yang diberi nama "Tani Niaga" dengan berbasis aplikasi website yang dapat diakses dengan handphone serta komputer secara online. Mengingat peran dan fungsi Dinas Pertanian Kabupaten Grobogan dalam memberdayakan dan melayani masyarakat tani, Dinas Pertanian Kabupaten Grobogan memiliki misi untuk dapat membawa masyarakat tani dapat bersaing di tingkat pasar lokal dan global serta meningkatkan posisi tawar petani di Kabupaten Grobogan.

Tani Niaga merupakan sistem yang dibuat untuk memfasilitasi petani dalam memasarkan produk hasil pertaniannya, memotong rantai tataniaga menjadi lebih pendek, menstabilkan harga saat panen raya, memperluas jangkauan pasar, dan memungkinkan petani mendapatkan pembeli dengan tawaran harga yang lebih tinggi sehingga berujung pada peningkatan pendapatan petani. Selain itu, e-marketing Tani Niaga ini menjadi salah satu strategi dan program untuk membangun dan membudayakan masa depan petani yang berwawasan TIK secara berkelanjutan (sustainable $e$ future). Pengimplementasian Tani Niaga di Kabupaten Grobogan ini diharapkan mampu membantu meningkatkan kapasitas petani untuk berpikir, bekerja, dan berkomunikasi dengan cara yang berbeda serta bermanfaat dalam pertumbuhan ekonomi.

E-marketing Tani Niaga merupakan inovasi pemasaran yang baru diterapkan kurang dari dua tahun oleh Dinas Pertanian Kabupaten Grobogan. Keberhasilan penerapan e-marketing Tani Niaga terjadi apabila adanya sinergi 
antar pengelola serta pengguna. Fasilitas e-marketing yang telah disediakan oleh Dinas Pertanian Kabupaten Grobogan ini tentunya perlu didukung oleh partisipasi petani sebagai pelaku agribisnis untuk mengimplementasikan program pengembangan Tani Niaga yang telah dibangun.

Penelitian Ningtyas et al. (2015) terkait faktor yang mempengaruhi penggunaan e-commerce pada pelaku UMKM di Kabupaten Banyumas dan Purbalingga menduga kesiapan organisasional, dorongan eksternal, dan sikap terhadap penggunaan teknologi berpengaruh terhadap penggunaan (adopsi) e-commerce. Hasil penelitian menunjukkan bahwa faktor yang berpengaruh positif dan signifikan terhadap adopsi e-commerce oleh pelaku UMKM Kabupaten Banyumas dan Purbalingga, yaitu faktor dorongan eksternal dan sikap terhadap penggunaan teknologi.

Penelitian Hanum dan Sinarasri (2017) juga menganalisis faktor-faktor yang memengaruhi adopsi e-commerce oleh pelaku UMKM di Kota Semarang. Penelitian ini menduga bahwa terdapat beberapa faktor yang memengaruhi pemanfaatan atau pengadopsian $e$ commerce oleh pelaku UMKM, di antaranya faktor teknologi, organisasional, lingkungan, dan individual. Hasil penelitan menunjukkan bahwa faktor yang secara parsial berpengaruh positif dan signifikan terhadap adopsi e-commerce, yaitu faktor teknologi dan individual. Sebaliknya, faktor organisasional secara parsial berpengaruh negatif dan tidak signifikan terhadap adopsi e-commerce dan faktor lingkungan secara parsial berpengaruh positif dan tidak signifikan terhadap adopsi e-commerce pada UMKM di Kota Semarang.

Penelitian Mulyandari (2011) terkait pemanfaatan cyber extension sebagai media komunikasi dalam pemberdayaan petani sayuran juga menganalisis faktor yang memengaruhi pemanfaatan cyber extension oleh petani sayuran untuk mendukung kegiatan usahatani. Dalam penelitian ini, variabel yang diduga memengaruhi petani dalam memanfaatkan teknologi, di antaranya karakteristik individu, faktor lingkungan, persepsi petani akan karakteristik cyber extension, dan perilaku pemanfaatan teknologi informasi. Dan hasil penelitian menunjukkan bahwa ada tiga variabel yang secara nyata memengaruhi perilaku petani dalam memanfaatkan cyber extension, di antaranya karakteristik individu, persepsi petani akan karakteristik cyber extension, dan perilaku pemanfaatan teknologi informasi.

Penelitian Dasli (2015) terkait pemanfaatan cyber extension oleh petani anggrek menganalisis faktor yang memengaruhi pemanfaatan cyber extension untuk mendukung kegiatan usahatani. Dalam penelitian ini, variabel yang diduga memengaruhi petani dalam memanfaatkan cyber extension, di antaranya hubungan karakteristik petani dan lingkungan. Hasil penelitian menunjukkan bahwa karakteristik petani dan lingkungan memiliki hubungan 
nyata dengan tingkat pemanfaatan cyber extension dalam mengembangkan usahatani.

Oleh karena itu, tujuan penelitian ini adalah menganalisis faktor-faktor apa saja yang memengaruhi petani dalam memanfaatkan e-marketing Tani Niaga sebagai media pemasaran online produk agribisnis.

\section{METODE PENELITIAN Lokasi dan Waktu Penelitian}

Lokasi penelitian dilakukan di Kabupaten Grobogan, Provinsi Jawa Tengah. Hal ini berdasarkan pertimbangan bahwa Kabupaten Grobogan merupakan kabupaten yang menerapkan e-marketing dalam pertanian bernama Tani Niaga yang dikelola oleh Dinas Pertanian dengan tujuan untuk memasarkan produk agribisnis.

\section{Metode Penentuan Responden}

Sampel yang dipilih dalam penelitian ini, yaitu petani pangan dan hortikultura yang memanfaatkan Tani Niaga. Pemilihan kedua kelompok sampel petani dilakukan menggunakan metode purposive sampling karena tanaman pangan dan hortikultura menjadi fokus pengembangan bagi Dinas Pertanian Kabupaten Grobogan dalam implementasi Tani Niaga. Pemilihan petani ditentukan berdasarkan komoditas terpilih dari masing-masing kelompok secara simple random untuk mewakili masing-masing produk agribisnis yang dipasarkan. Jumlah sampel pada kelompok petani pangan dan hortikultura masing-masing sebanyak 57 petani. Subjek penelitian lain yang dipilih sesuai pertimbangan dan tujuan penelitian (purposive sampling) adalah informan dari pihak Dinas Pertanian Kabupaten Grobogan.

\section{Data dan Instrumen Penelitian}

Penelitian ini menggunakan jenis data primer dan sekunder. Pengumpulan data primer diperoleh dari hasil pengamatan, wawancara, maupun diskusi dengan sejumlah subjek penelitian terpilih. Sedangkan data sekunder diperoleh dari website Tani Niaga, website Dinas Pertanian Kabupaten Grobogan, website Badan Pusat Statistik, buku, jurnal, artikel, internet serta literature lain yang terkait dengan topik penelitian. Penelitian ini merupakan penelitian survei yang datanya dikumpulkan dari informan dengan menggunakan instrumen dalam bentuk kuesioner

\section{Metode Pengolahan dan Analisis Data}

Pengolahan data dilakukan dengan analisis kuantitatif yang dilengkapi dengan informasi berdasarkan data kualitatif. Analisis kuantitatif yang digunakan dalam penelitian ini, yaitu analisis Partial Least Square (PLS) menggunakan software SmartPLS 3.

Analisis Partial Least Square (PLS) digunakan untuk menjawab permasalahan faktor apa saja yang memengaruhi tingkat pemanfaatan $e$ marketing Tani Niaga dengan menganalisis pengaruh antar variabel penelitian. PLS terdiri dari model 
pengukuran (outer model) dan model struktural (inner model). Model pengukuran menjelaskan hubungan antara variabel yang diamati (manifest variable) dengan variabel laten, sedangkan model struktural menjelaskan hubungan antara variabel laten. Oleh karena itu, model PLS diinterpretasikan dalam dua tahap, yaitu pertama validitas dan reliabilitas dari model pengukuran, kedua adalah model struktural dinilai dengan mengevaluasi persentase variance yang dijelaskan oleh nilai $\mathrm{R}^{2}$ ( $R$-Square) untuk variabel endogen dan tingkat signifikansi koefisien jalur (Ghozali dan Latan, 2015).

Model persamaan struktural dengan pendekatan Partial Least Square (PLS) dalam penelitian ini terdiri dari dua variabel, yaitu variabel bebas (independent variable) dan variabel terikat (dependent variable). Variabel bebas terdiri dari karakteristik individu, faktor lingkungan, karakteristik $e$ marketing Tani Niaga, dan perilaku dalam pemanfaatan e-marketing Tani Niaga. Variabel terikat dalam penelitian ini adalah tingkat pemanfaatan $e$ marketing Tani Niaga. Indikator untuk masing-masing variabel yang digunakan dalam penelitian ini, di antarannya:

1. Indikator variabel karakteristik individu petani: umur, pendidikan formal, lama berusahatani, luas penguasaan lahan, keberanian mengambil resiko, dan motivasi.

2. Indikator variabel faktor lingkungan: ketersediaan, kualitas serta aksesbilitas infrastruktur jaringan TIK, dan ketersediaan dukungan keluarga.

3. Indikator variabel karakteristik Tani Niaga: kesesuaian dengan kebutuhan, kemudahan untuk mengoperasikan aplikasi, dan keuntungan relatif.

4. Indikator variabel perilaku petani dalam memanfaatkan Tani Niaga: pengetahuan tentang sistem pemasaran online, sikap terhadap aplikasi sistem pemasaran online, dan keterampilan dalam pemanfaatan TI.

5. Indikator variabel tingkat pemanfaatan Tani Niaga: tingkat akses sarana TI, intensitas pemanfaatan sistem pemasaran online, tingkat manfaat yang dirasakan, dan jangkauan pemasaran melalui sistem pemasaran online.

\section{HASIL DAN PEMBAHASAN}

Hasil uji signifikansi dari seluruh hipotesis yang dibangun pada kelompok petani pangan dan petani hortikultura dalam penelitian ini dapat dilihat pada Tabel 1.

Tabel 1. Nilai Koefisien Pengaruh dan T-Statistics Antara Variabel yang Diduga Memengaruhi Tingkat Pemanfaatan Tani Niaga

\begin{tabular}{lllll}
\hline \multirow{2}{*}{ Variabel } & \multicolumn{2}{c}{ Petani Pangan } & \multicolumn{2}{c}{ Petani Hortikultura } \\
\cline { 2 - 5 } & $\begin{array}{c}\text { Koefisien } \\
\text { Pengaruh }\end{array}$ & T Statistics & $\begin{array}{l}\text { Koefisien } \\
\text { Pengaruh }\end{array}$ & T Statistics \\
\hline
\end{tabular}




\begin{tabular}{lcccc}
\hline Karakteristik Individu & 0,412 & $3,949 *$ & 0,605 & $5,694^{*}$ \\
Faktor Lingkungan & $-0,063$ & 0,581 & 0,063 & 0,644 \\
Karakteristik Tani Niaga & 0,498 & $4,904^{*}$ & 0,201 & $2,042 *$ \\
Perilaku Petani & 0,120 & 0,799 & 0,074 & 0,430 \\
\hline
\end{tabular}

*t(0,1): 1,645

Hasil uji bootstrapping pada kedua model, yaitu model petani pangan dan petani hortikultura menunjukkan bahwa terdapat kesamaan faktor yang memengaruhi tingkat pemanfaatan Tani Niaga. Masing-masing faktor yang secara nyata memberikan pengaruh terhadap tingkat pemanfaatan Tani Niaga adalah karakteristik individu dan karakteristik Tani Niaga. Indikator tingkat pemanfaatan Tani Niaga yang paling berkontribusi untuk menjelaskan variabel tingkat pemanfaatan Tani Niaga pada model petani pangan dan hortikultura, yaitu tingkat akses sarana TI $\left(\mathrm{Y}_{1}\right)$. Tingkat akses sarana TI oleh petani pangan dan hortikultura dipengaruhi oleh faktor karakteristik individu dan karakteristik Tani Niaga. Hal ini ditunjukkan dari nilai loading factor tingkat akses sarana TI $\left(\mathrm{Y}_{1}\right)$ paling besar dibanding indikator lainnya pada model petani pangan dan petani hortikultura, masing-masing yaitu sebesar 0,914 dan 0,898 yang berarti indikator tingkat akses sarana TI mencerminkan variebal tingkat pemanfaatan Tani Niaga secara relevan sebesar 91,4 persen dan 89,8 persen. Kontribusi indikator karakteristik individu petani berdasarkan nilai loading factor dapat dilihat pada Tabel 2 .

Tabel 2. Kontribusi Indikator Tingkat Pemanfaatan Tani Niaga Berdasarkan Nilai Loading Factor

\begin{tabular}{lcc}
\hline \multicolumn{1}{c}{ Indikator } & \multicolumn{2}{c}{ Loading Factor } \\
\cline { 2 - 3 } Tingkat Pemanfaatan Tani Niaga & Petani Pangan & Petani Hortikultura \\
\hline Tingkat Akses Sarana TI $\left(\mathrm{Y}_{1}\right)$ & $\mathbf{0 , 9 1 4}$ & $\mathbf{0 , 8 9 8}$ \\
Intensitas Pemanfaatan Tani Niaga $\left(\mathrm{Y}_{2}\right)$ & 0,899 & 0,892 \\
\hline
\end{tabular}

\section{Pengaruh Karakteristik Petani terhadap Tingkat Pemanfaatan Tani Niaga}

Berdasarkan hasil uji bootstrapping PLS pada model petani pangan dan petani hortikultura menunjukkan bahwa karakteristik individu petani pada kedua kelompok petani memiliki pengaruh positif secara signifikan terhadap tingkat pemanfaatan Tani Niaga pada taraf nyata
10 persen. Hal tersebut didasarkan atas nilai koefisien pengaruh pada masingmasing kelompok dan nilai $t$-statistcs. Nilai korelasi koefisien pengaruh jalur dan $t$-statistics variabel karakteristik

individu petani dapat dilihat pada Tabel 3.

Tabel 3 menunjukkan bahwa nilai koefisien pengaruh pada kelompok petani pangan dan petani hortikultura 
masing-masing sebesar 0,412 dan 0,605. Nilai $t$-statistics kelompok petani pangan dan petani hortikultura masing-masing sebesar 3,949 dan 5,694 lebih besar dari t-table $(1,645)$ pada selang kepercayaan 90 persen sehingga dari hasil nilai tersebut maka dapat diartikan bahwa karakteristik individu kelompok petani pangan, dan petani hortikultura berpengaruh positif pada tingkat pemanfaatan Tani Niaga secara signifikan.

\section{Tabel 3. Pengaruh Karakteristik Individu Petani Terhadap Tingkat Pemanfaatan Tani Niaga Berdasarkan Koefisien Pengaruh dan $T$ -} Statistics

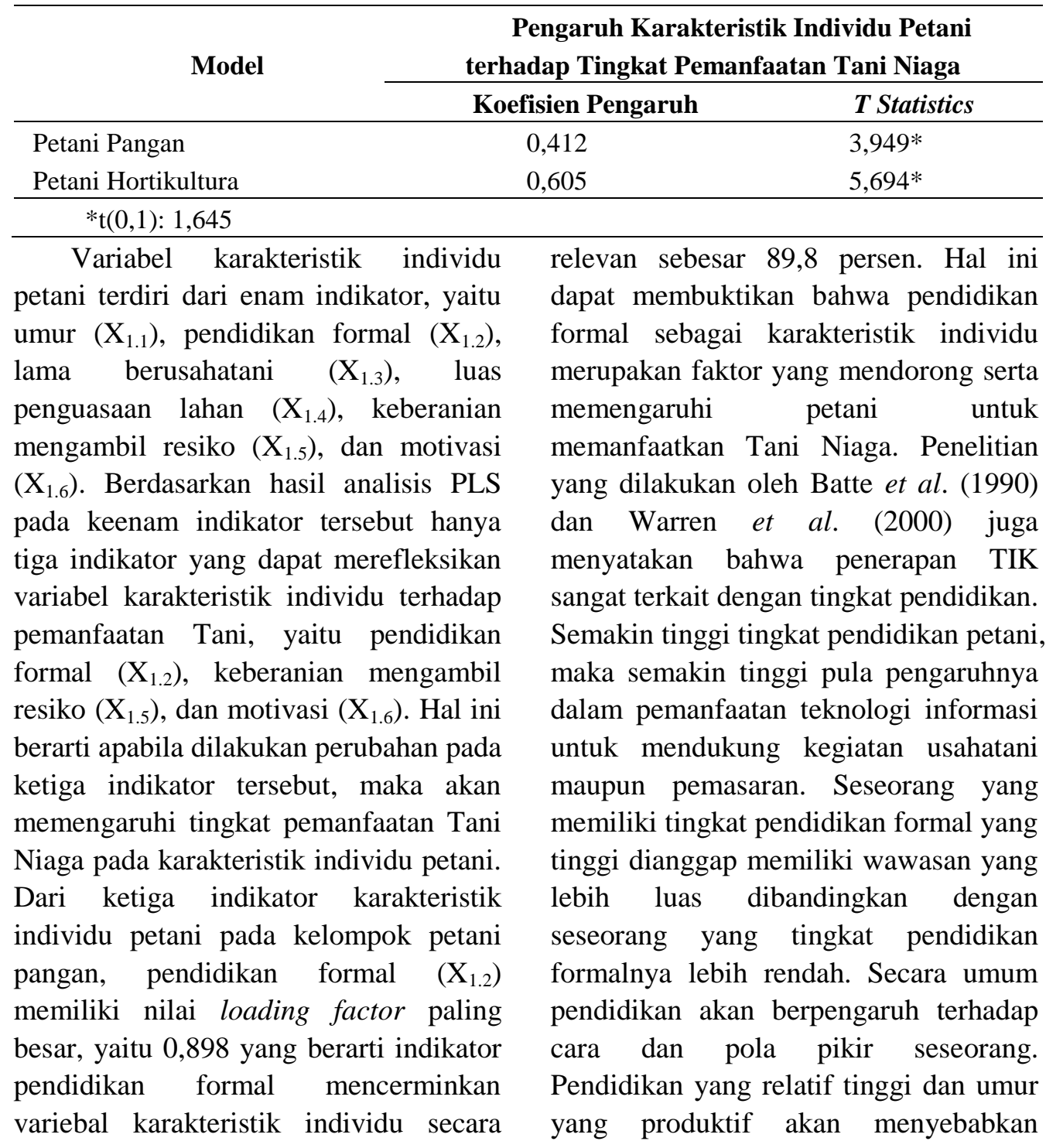


seseorang menjadi dinamis. Yuantari et al. (2016) menyatakan bahwa rendahnya tingkat pendidikan menyebabkan rendahnya kemampuan petani dalam hal pemanfaatan teknologi yang dapat menghambat pertumbuhan perekonomian pada petani.

Pada model petani hortikultura, indikator yang memiliki nilai loading factor paling besar, yaitu keberanian mengambil resiko $\left(X_{1.5}\right)$ sebesar 0,934 yang berarti indikator keberanian mengambil resiko mencerminkan karakteristik individu secara relevan sebesar 93,4 persen. Hal ini sesuai pada penelitian Agussabti (2002) yang menemukan bahwa adanya pengaruh positif antara keberanian mengambil resiko terhadap pengambilan keputusan untuk mengadopsi suatu inovasi. Nilai loading factor ini menunjukkan bahwa adanya perbedaan antara kelompok petani pangan dan petani hortikultura dalam menjelaskan karakteristik individu dalam memengaruhi tingkat akses saran TI dalam mendukung kegiatan pemasaran petani melalui Tani Niaga. Kontribusi indikator karakteristik individu petani berdasarkan nilai loading factor dapat dilihat pada Tabel 4.

Tabel 4. Kontribusi indikator karakteristik individu petani berdasarkan nilai loading factor

\begin{tabular}{lcc}
\hline \multicolumn{1}{c}{ Indikator } & \multicolumn{2}{c}{ Loading Factor } \\
\cline { 2 - 3 } Karakteristik Individu Petani & Petani Pangan & Petani Hortikultura \\
\hline Pendidikan Formal $\left(\mathrm{X}_{1.2}\right)$ & $\mathbf{0 , 8 9 8}$ & 0,896 \\
Keberanian Mengambil Resiko $\left(\mathrm{X}_{1.5}\right)$ & 0,710 & $\mathbf{0 , 9 3 4}$ \\
Motivasi $\left(\mathrm{X}_{1.6}\right)$ & 0,863 & 0,867 \\
\hline
\end{tabular}

Pengaruh Faktor Lingkungan terhadap Tingkat Pemanfaatan Tani Niaga

Berdasarkan hasil uji bootstrapping PLS pada model petani pangan dan petani hortikultura menunjukkan bahwa faktor lingkungan pada kelompok petani pangan memiliki pengaruh negatif, sedangkan pada kelompok petani hortikultura memiliki pengaruh positif namun kedua model tidak signifikan terhadap pemanfaatan Tani Niaga pada taraf nyata 10 persen. Hal tersebut didasarkan atas nilai koefisien pengaruh pada masing-masing kelompok dan nilai t-statistcs. Nilai korelasi koefisien pengaruh jalur dan $t$-statistics variabel faktor lingkungan dapat dilihat pada Tabel 5. 
Tabel 5. Pengaruh Faktor Lingkungan Terhadap Tingkat Pemanfaatan Tani Niaga Berdasarkan Koefisien Pengaruh dan $\boldsymbol{T}$-Statistics

\begin{tabular}{lcc}
\hline \multirow{2}{*}{ Model } & \multicolumn{2}{c}{ Pengaruh Lingkungan terhadap } \\
& \multicolumn{2}{c}{ Tingkat Pemanfaatan Tani Niaga } \\
\cline { 2 - 3 } & Koefisien Pengaruh & T Statistics \\
\hline Petani Pangan & $-0,063$ & 0,581 \\
Petani Hortikultura & 0,063 & 0,644 \\
\hline$* \mathrm{t}(0,1): 1,645$ & & \\
\hline
\end{tabular}

Tabel 5 menunjukkan bahwa nilai koefisien pengaruh pada model petani pangan dan petani hortikultura masingmasing sebesar $-0,063$ dan 0,063. Nilai t-statistics kelompok petani pangan dan petani hortikultura masing-masing sebesar 0,581 dan 0,644 kurang dari $t$ table $(1,645)$ pada selang kepercayaan 90 persen. Hasil nilai tersebut menunjukkan bahwa faktor lingkungan tidak berpengaruh secara signifikan terhadap pemanfaatan Tani Niaga. Pada penelitian ini, faktor lingkungan yang terdiri dari dua indikator, yaitu ketersediaan, kualitas, dan aksesbilitas infrastruktur jaringan TIK $\left(\mathrm{X}_{2.1}\right)$ dan ketersediaan dukungan keluarga dalam pemasaran secara konvensional maupun pemanfaatan sistem pemasaran online $\left(\mathrm{X}_{2.2}\right)$. Berdasarkan hasil analisis PLS, kedua indikator tersebut dapat merefleksikan variabel faktor lingkungan terhadap pemanfaatan Tani Niaga. Namun, faktor lingkungan ternyata tidak memiliki pengaruh secara signifikan pada petani untuk memanfaatkan Tani Niaga. Bahkan pada petani pangan, faktor lingkungan memiliki pengaruh yang negatif. Petani di Kabupaten Grobogan memanfaatkan Tani Niaga atas dasar keputusannya pribadi. Meski infrastruktur yang ada memadai dan adanya dukungan keluarga untuk menggunakan sistem pemasaran online, namun hal tersebut belum mampu meningkatkan pemanfaatan Tani Niaga oleh petani tersebut. Hal ini disebabkan oleh kebiasaan petani setempat yang memiliki budaya pemasaran secara langsung tidak dapat dirubah dalam waktu yang singkat. Selain itu, tidak semua petani menguasai penggunaan teknologi internet. Masih ada sebagian petani yang rendah dalam penguasaan teknologi internet bahkan belum dapat mengoperasikan smartphone, apalagi petani yang sudah berusia sekitar 40 tahun ke atas memiliki minat yang rendah dalam memanfaatkan internet dalam kegiatan pertanian.

Penelitian yang dilakukan oleh Mulyandari (2011) juga menunjukkan bahwa faktor lingkungan tidak berpengaruh signifikan terhadap pemanfaatan cyber extension dan lebih dipengaruhi oleh karakteristik individu petani. Lain halnya dalalm kegiatan usahatani, penelitian Tamba (2007) bahwa salah satu faktor keberhasilan petani dalam berusahatani adalah lingkungan fisik yang diantaranya adalah infrastruktur, sarana angkutan, saluran pengairan, dan modal usaha. Gultom (2016) pun menunjukkan adanya 
pengaruh positif dari faktor lingkungan termasuk dorongan dan persetujuan anggota keluarga untuk menggunakan sumber informasi berbasis TIK dan konvensional.

\section{Pengaruh Karakteristik Tani Niaga terhadap Tingkat Pemanfaatan Tani Niaga}

Berdasarkan hasil uji bootstrapping PLS pada model petani pangan dan petani hortikultura menunjukkan bahwa karakteristik Tani Niaga pada kedua model kelompok petani memiliki pengaruh positif secara signifikan terhadap pemanfaatan Tani Niaga pada taraf nyata 10 persen. Hal tersebut didasarkan atas nilai koefisien pengaruh pada masing-masing model dan nilai $t$ statistcs. Nilai korelasi koefisien pengaruh jalur dan $t$-statistics variabel karakteristik Tani Niaga dapat dilihat pada Tabel 6.

Tabel 6 menunjukkan bahwa nilai koefisien pengaruh pada model petani pangan dan petani hortikultura masingmasing sebesar 0,498 dan 0,201 . Nilai $t$ statistics kelompok petani pangan dan petani hortikultura masing-masing sebesar 4,904 dan 2,042 lebih besar dari t-table $(1,645)$ pada selang kepercayaan 90 persen sehingga dari hasil nilai tersebut maka dapat diartikan bahwa karakteristik Tani Niaga berpengaruh positif pada tingkat pemanfaatan Tani Niaga secara signifikan.

\section{Tabel 6. Pengaruh Karakteristik Tani Niaga Terhadap Tingkat Pemanfaatan} Tani Niaga Berdasarkan Koefisien Pengaruh dan T-Statistics

\begin{tabular}{lcc}
\hline \multirow{2}{*}{ Model } & \multicolumn{2}{c}{$\begin{array}{c}\text { Pengaruh Persepsi Petani terhadap } \\
\text { Tingkat Pemanfaatan Tani Niaga }\end{array}$} \\
\cline { 2 - 3 } & Koefisien Pengaruh & T Statistics \\
\hline Petani Pangan & 0,498 & $4,904^{*}$ \\
Petani Hortikultura & 0,201 & $2,042^{*}$ \\
\hline$* t(0,1): 1,645$ & &
\end{tabular}

$* \mathrm{t}(0,1): 1,645$

Variabel karakteristik Tani Niaga terdiri dari tiga indikator, yaitu kesesuaian dengan kebutuhan $\left(\mathrm{X}_{3.1}\right)$, kemudahan untuk diaplikasikan $\left(\mathrm{X}_{3.2}\right)$, dan keuntungan relatif $\left(\mathrm{X}_{3.3}\right)$. Berdasarkan hasil analisis data, ketiga indikator dapat merefleksikan variabel karakteristik Tani Niaga terhadap pemanfaatan Tani Niaga. Kontribusi indikator karakteristik Tani Niaga berdasarkan nilai loading factor dapat dilihat pada Tabel 7. Dari masing- masing indikator tersebut, indikator kesesuaian dengan kebutuhan $\left(\mathrm{X}_{3.1}\right)$ pada kelompok petani pangan memiliki nilai loading factor paling besar, yaitu 0,832 . Apabila suatu inovasi itu sesuai dengan kebutuhan petani maka inovasi tersebut akan menjadi bagian utama untuk mencapai tujuannya. Begitu halnya dengan Tani Niaga, Tani Niaga sebagai media pemasaran online produk hasil 
pertanian tentunya memiliki fungsi untuk membantu dan mempermudah petani dalam memasarkan hasil pertaniannya sehingga hal tersebut menjadi salah satu kebutuhan petani. Selain itu, hal ini didukung oleh penelitian Tornatsky dan Klein (1982) yang menemukan bahwa suatu inovasi diadopsi ketika inovasi tersebut sesuai dengan tanggung jawab kerja individu. Selain itu, Thompson et al. (1991) juga menemukan adanya pengaruh yang signifikan antara kesesuaian tugas dengan pemanfaatan teknologi informasi.

Pada kelompok petani hortikultura, indikator yang memiliki nilai loading factor paling besar adalah kemudahan untuk diaplikasikan $\left(\mathrm{X}_{3.2}\right)$ senilai 0,839 sehingga kemudahan untuk diaplikasikan memiliki kontribusi terbesar dalam menjelaskan karakteristik Tani Niaga dalam memengaruhi tingkat pemanfaatan Tani Niaga. Penelitian yang dilakukan oleh Tornatzky dan Klein (1982) menemukan bahwa semakin komplek inovasi yang dilakukan pada suatu teknologi informasi, maka akan semakin rendah tingkat adopsi atau penerimaannya. Thompson et al. (1991) juga menemukan adanya pengaruh yang signifikan dan negatif antara kompleksitas dan pemanfaatan teknologi informasi. Oleh karena itu, tinggi rendahnya penerimaan dan pemanfaatan Tani Niaga akan dipengaruhi oleh kompleksitas dari sistem Tani Niaga yang diterapkan karena apabila suatu inovasi tersebut sulit digunakan maka akan membuat petani tidak tertarik untuk memanfaatkannya.

\section{Tabel 7. Kontribusi Indikator Karakteristik Tani Niaga Berdasarkan Nilai} Loading Factor

\begin{tabular}{lcc}
\hline \multicolumn{1}{c}{ Indikator } & \multicolumn{2}{c}{ Loading Factor } \\
\cline { 2 - 3 } Karakteristik Tani Niaga & Petani Pangan & Petani Hortikultura \\
\hline Kesesuaian dengan kebutuhan $\left(\mathrm{X}_{3.1}\right)$ & $\mathbf{0 , 8 3 2}$ & 0,666 \\
Kemudahan untuk diaplikasikan $\left(\mathrm{X}_{3.2}\right)$ & 0,757 & $\mathbf{0 , 8 3 9}$ \\
Keuntungan relatif $\left(\mathrm{X}_{3.3}\right)$ & 0,669 & 0,731 \\
\hline
\end{tabular}

Pengaruh Perilaku Petani terhadap Tingkat Pemanfaatan Tani Niaga

Berdasarkan hasil uji bootstrapping PLS pada model petani pangan dan petani hortikultura menunjukkan bahwa perilaku petani dalam memanfaatkan Tani Niaga pada kedua model kelompok petani memiliki pengaruh positif namun tidak signifikan terhadap tingkat pemanfaatan Tani Niaga pada taraf nyata 10 persen. Hal tersebut didasarkan atas nilai koefisien pengaruh pada masingmasing kelompok dan nilai t-statistcs. Nilai korelasi koefisien pengaruh jalur dan $t$-statistics variabel perilaku petani dalam memanfaatkan Tani Niaga dapat dilihat pada 8 . 
Tabel 8. Pengaruh Perilaku Petani Dalam Memanfaatkan Tani Niaga Terhadap Tingkat Pemanfaatan Tani Niaga Berdasarkan Koefisien Pengaruh dan T-Statistics

\begin{tabular}{lcc}
\hline \multirow{2}{*}{ Model } & \multicolumn{2}{c}{$\begin{array}{c}\text { Pengaruh Perilaku Petani terhadap } \\
\text { Tingkat Pemanfaatan Tani Niaga }\end{array}$} \\
\cline { 2 - 3 } & Koefisien Pengaruh & T Statistics \\
\hline Petani Pangan & 0,120 & 0,799 \\
Petani Hortikultura & 0,074 & 0,430 \\
\hline$* \mathrm{t}(0,1): 1,645$ & & \\
\hline
\end{tabular}

Tabel 8 menunjukkan bahwa nilai koefisien pengaruh pada model kelompok petani pangan dan petani hortikultura masing-masing sebesar 0,120 dan 0,074 . Nilai t-statistics kelompok petani pangan dan petani hortikultura masing-masing sebesar 0,799 dan 0,430 kurang dari t-table $(1,645)$ pada selang kepercayaan 90 persen sehingga dari hasil nilai tersebut maka dapat diartikan bahwa perilaku petani tidak berpengaruh secara signifikan terhadap pemanfaatan Tani Niaga.

Hasil penelitian memperlihatkan
bahwa perilaku petani dalam memanfaatkan Tani Niaga terdiri dari tiga indikator, yaitu pengetahuan tentang sistem pemasaran online $\left(\mathrm{X}_{4.1}\right)$, sikap terhadap aplikasi sistem pemasaran online $\left(\mathrm{X}_{4.2}\right)$, dan keterampilan dalam pemanfaatan teknologi informasi $\left(\mathrm{X}_{4.3}\right)$ berpengaruh positif namun tidak signifikan terhadap pemanfaatan Tani Niaga. Secara psikologis, petani mengetahui aplikasi Tani Niaga, merespon positif adanya Tani Niaga, dan dapat menggunakan teknologi informasi secara mandiri, namun hal tersebut belum mampu meningkatkan intensitas maupun frekuensi mengakses serta

memanfaatkan Tani Niaga sebagai media pemasaran online karena petanipetani masih terbiasa melakukan kegiatan pemasaran secara tatap muka langsung dengan pelanggannya. Budaya kekerabatan dan kekeluargaan masih melekat pada petani Kabupaten Grobogan. Petani masih cenderung lebih memilih menjual produk hasil pertaniannya kepada orang yang sudah dikenalnya dan menjadi langganan sehingga secara emosional ada keterikatan antara kedua belah pihak.

Hasil ini juga serupa dengan penelitian yang dilakukan oleh Thompson et al. (1991) dan Istiqomah (2010) yang memperlihatkan bahwa perilaku tidak memiliki pengaruh yang signifikan terhadap pemanfaatan teknologi informasi. Namun lain halnya dengan penelitian yang dilakukan oleh Mulyandari (2011) yang menunjukkan bahwa perilaku petani dalam memanfaatkan teknologi informasi ternyata berpengaruh secara signifikan terhadap pemanfaatan cyber extension. 


\section{SIMPULAN DAN SARAN \\ Simpulan}

Tingkat Pemanfaatan Tani Niaga dipengaruhi oleh karakteristik individu petani dan karakteristik Tani Niaga. Faktor karakteristik individu pada petani pangan yang dominan berpengaruh nyata terhadap tingkat pemanfaatkan Tani Niaga adalah pendidikan formal, sedangkan pada kelompok petani hortikultura adalah keberanian mengambil resiko. Faktor karakteristik Tani Niaga yang dominan berpengaruh nyata terhadap tingkat pemanfaatan Tani Niaga pada kelompok petani pangan adalah kesesuaian dengan kebutuhan, sedangkan pada kelompok petani hortikultura adalah kemudahan untuk diaplikasikan.

\section{Saran}

1. Meningkatkan kapasitas petani dengan melakukan pelatihan dan pendidikan bagi petani secara berkala untuk meningkatkan kemampuan dan pengetahuan, terutama di bidang teknologi informasi berbasis internet dan sistem pemasaran online.

2. Guna mendukung dan meningkatkan pemanfaatan Tani Niaga oleh petani, maka Dinas Pertanian Kabupaten Grobogan perlu meningkatkan kegiatan sosialisasi terkait penerapan Tani Niaga dan menyebarluaskan informasi penggunaan sistem pemasaran online untuk produk pertanian, merekrut tenaga kerja khusus teknologi informasi dan berinvestasi dalam penyediaan teknologi internet dan pelatihan bagi pekerjanya serta dapat melakukan kerjasama dengan pihak swasta dalam meningkatkan sumber pendanaan, edukasi, dan kegiatan promosi iklan.

\section{DAFTAR PUSTAKA}

Agussabti. 2002. Kemandirian Petani dalam Pengambilan Keputusan Adopsi Inovasi (Kasus Petani Sayuran di Provinsi Jawa Barat). [Disertasi]. Program Pascasarjana. Institut Pertanian Bogor, Bogor.

Asmarantaka, Ratna Winandi. 2014. Pemasaran Agribisnis (Agrimarketing). IPB Press. Bogor.

Batte, Marvin T, Eugene Jones, dan Gary D. Schnitkey. 1990. Computer Use by Ohio Commercial Farmers. American Journal of Agricultural Economics, 72 (4): 935-945.

Chandra, Gregorius, Fandy Tjiptono, dan Yanto Chandra. 2006. Pemasaran Global: Internasionalisasi dan Internetisasi. Penerbit Andi. Yogyakarta.

Dasli, Aira Putri Eri. 2015. Pemanfaatan Cyber Extension melalui Telepon Genggam oleh Petani Anggrek di Taman Anggrek Ragunan Jakarta Selatan. [Tesis]. Program Pascasarjana. Institut Pertanian Bogor, Bogor. 
Eid, Riyad dan Myfanwy Trueman. 2002. The Internet: New International Marketing Issues. Management Research News, 25 (12): 54-67.

Ghozali, Imam dan Hengky Latan. 2015. Partial Least Square Konsep, Teknik, dan Aplikasi Menggunakan Program SmartPLS 3.0. Universitas Diponegoro. Semarang.

Gultom, Dame Trully. 2016. Perilaku Komunikasi Petani Sayuran dalam Memenuhi Kebutuhan Informasi Pertanian melalui Cyber Extension di Provinsi Lampung. [Tesis]. Institut Pertanian Bogor, Bogor.

Hanum, Ayu Noviani, Andwiani Sinarasri. 2017. Analisis FaktorFaktor yang Mempengaruhi Adopsi E-Commerce dan Pengaruhnya terhadap Kinerja UMKM (Studi Kasus UMKM di Wilayah Kota Semarang). MAKSIMUM, 1 (1): 1-15.

Iddings, R. Keith dan Jerold W. Apps. 1990. What Influences Farmers' Computer Use?. Journal of Extension, 28 (1).

Istiqomah, Inuk Wahyuni. 2010. FaktorFaktor yang Memengaruhi Pemanfaatan Teknologi Informasi dan Pengaruh Pemanfaatan Teknologi Informasi terhadap Kinerja Individual. Jurnal Akuntansi Riset, 2 (1): 307-318.

[Kemenkeu] Kementerian Keuangan Republik Indonesia. 2016. Presiden Luncurkan Program
Sinergi Aksi untuk Ekonomi Rakyat. http://www.kemenkeu.go.id/. Diakses 12 Maret 2018].

[Kemenkominfo]

Kementerian

Komunikasi dan Informatika

Republik Indonesia. 2015.

Klasifikasi Jasa yang Digunakan dalam Transaksi Online Tahun $2015 . \quad$ http:// statistik.kominfo.go.id/. Diakses 15 Maret 2018.

[Kemenkominfo] Kementerian Komunikasi dan Informatika Republik Indonesia. 2015. Klasifikasi Produk yang Dibeli Secara Online Tahun 2015. http:// statistik.kominfo.go.id/. Diakses 15 Maret 2018.

Kotler, Philip dan Gary Armstrong. 2018. Principles of Marketing. Edisi 17. Pearson Education. London.

Liu, Hang, Yuming Wang, dan Kui Xie. 2013. Agricultural E-Commerce Sites Evaluation Research. International Journal of Business and Social Science, 4 (17): 138143.

Lu, Jinhai. 2015. The Entire ECommerce Application in Guangxi Fruit Industry. International Symposium on Social Science. http://download.atlantis-press.com. Diunduh 13 Januari 2019.

Mohammed, Rafi A., Robert J. Fisher, Bernard J. Jaworski, dan Gordon J. Paddison. 2003. Internet Marketing: Building Advantage in 
a Networked Economy. McGrawHill Companies. New York.

Mulyandari, Retno Sri Hartati. 2011. Cyber Extension Sebagai Media Komunikasi dalam Pemberdayaan Petani Sayuran. [Tesis]. Program Pascasarjana. Institut Pertanian Bogor, Bogor.

Ningtyas, Pinky Kusumu, Bambang Sunarko, Jaryono. 2015. Analisis Faktor yang Mempengaruhi Adopsi E-Commerce dan Pengaruhnya terhadap Kinerja UMKM. Performance, 21 (1): 95107.

Nurmalina, Rita. 2014. Pemasaran: Konsep dan Aplikasi. IPB Press. Bogor.

Tamba, Mariati. 2007. Kebutuhan Informasi Pertanian dan Aksesnya Bagi Petani Sayuran: Pengembangan Model Penyediaan Informasi Pertanian dalam Pemberdayaan Petani, Kasus di Provinsi Jawa Barat. [Disertasi]. Program Pascasarjana. Institut Pertanian Bogor, Bogor.

Thompson, Ronald L., Christopher A. Higgins, dan Jane M. Howell. 1991. Personal Computing: Toward A Conceptual Model of Utilization. MIS Quarterly, 15 (1): 125-143.

Tornatzky, Louis G. dan Katherine J. Klein. 1982. Innovation Characteristics and Innovation Adoption-Implementation: A Meta-Analysis of Findings. IEEE
Transactions on Engineering Management, 29 (1): 28-45.

Warren, Martyn Frank, R. J. Soffe, dan M. A. H. Stone. 2000. Farmers, Computers and The Internet: A Study of Adoption in Contrasting Regions of England. Farm Management, 10 (11): 665-684.

Yuantari, M. G. Catur, Arif Kurniadi, dan Ngatindriatun. 2016. Pemanfaatan Teknologi Informasi untuk Meningkatkan Pemasaran Hasil Pertanian di Desa Curut Kecamatan Penawangan Kabupaten Grobogan Jawa Tengah. Techno.COM, 15 (1): 4347. 